SHS Web of Conferences 10, 00042 (2014)

DOI: $10.1051 /$ shsconf/20141000042

C Owned by the authors, published by EDP Sciences, 2014

\title{
The social assistance system - One of the ingredients of social inclusion policy
}

\author{
I. Skrodele-Dubrovska \\ Rīga Stradiņš University, Latvia
}

\begin{abstract}
Social assistance system is intended for persons who are not employed or have not been employed for a long period of time and do not receive the services from the national social security system or do not qualify for state social benefits, or do not generate sufficient income from work and do not provide means of subsistence for themselves or overcome particular difficulties of life and who are not receiving adequate assistance from anybody else. Socially excluded person is denied of or has difficulties to exercise their rights to obtain sufficient income, receive a range of essential services and goods, and also to defend their rights. Social exclusion means both reduced material resources, as well as inability to effectively participate in the economic, political and cultural life, loss of the feeling of belonging, which to some extent causes the sense of estrangement and alienation from the society. Thus, the emergence of poverty is not only affected by the personal lack of resources, but also the lack of availability of resources in the community. For instance, the locations of the existing social institutions whose services are required are too distant from the place of residence or poorly developed public transport network are the reasons that limit availability of the required social services. The nature of social exclusion is also related to the consistency and durability, in the sense that the longer the multitude of social problems is not addressed, the greater is the risk of social exclusion for the particular social groups. Lombardi indicates that "the objective of the social inclusion policy is to ensure the possibility to participate in social life, gain pleasure and enjoy high level of the quality of life, to each and every resident, irrespective of their social or economic

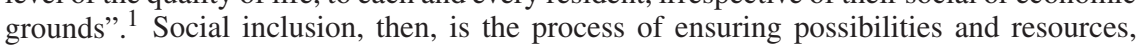
required to comprehensively participate in the economic, social and cultural life, ensure the prosperity and standard of living adopted in the society, as well as greater opportunities for participation in decision-making and access to fundamental human rights to the persons subjected to the risk of social exclusion and poverty.
\end{abstract}

\section{Introduction}

The current model of social assistance system of Latvia came into effect on January $1^{\text {st }} 2003$. It was formed as a decentralised system, in cooperation with the World Bank experts. The system is based on a differentiated provision of aid to people with low income. People who have lower income than the guaranteed level of income of the country may be eligible for financial (in some cases in-kind) support, receiving GMI allowance as the difference between GMI level and income of the person (household).

\footnotetext{
${ }^{1}$ Lombardi T.P., Inclusion: Policy and Practice, Phi Delta Kappa, Educational Foundation, 1999, P.10.

This is an Open Access article distributed under the terms of the Creative Commons Attribution License 4.0, which permits unrestricted use, distribution, and reproduction in any medium, provided the original work is properly cited.
} 


\section{SHS Web of Conferences}

The law of social services and social assistance ${ }^{2}$ (hereinafter referred to as the Law) lays down that the objective of social assistance is to provide material support to poor $^{3}$ and low-income families $^{4}$ (persons) that have come to a crisis situation, in order to satisfy the basic domestic needs of the parties and to stimulate participation of labour force persons in the improvement of their situation.

The Law sets out the basic principles for granting social assistance:

- Assessment of client's material resources and income and property;

- Provision of the essentials ${ }^{5}$ - food, clothing, housing, health care, compulsory education;

- Participation of labour force persons in improvement of their situation.

The Law defines ${ }^{6}$ the following social assistance benefits that are paid out of local government budget:

1) Benefit for provision of guaranteed minimum income level (hereinafter referred to as GMI benefit) - according to the rules and regulations of the Cabinet;

2) Housing benefit - according to regulatory provisions of municipality;

3) Other benefits - if a justified demand for GMI allowance and housing benefit is fulfilled, a municipality, after assessment of the income of a family (person), may pay also other benefits to satisfy the basic needs (health care, compulsory education etc.) of a family (person) - according to regulatory provisions of municipality;

4) A one-off allowance in case of an emergency - as an exemption from the point of view of social assistance basic principles, which municipality may grant without evaluation of income, if the person has got into an emergency situation as a result of unforeseeable circumstances and is unable to meet their own basic needs and the ones of family members.

The system is based on close cooperation of the municipality and people living in its territory (people/household applies for social assistance in local social services, and social service institutions carry out assessment of the material status of the person/household), and financing is assured from municipal resources.

I will take a look at the main changes in the situation from 2008 till 2011 which have happened mainly due to the effects of the global financial crisis and I will attract attention to the urgent data on the households registered in 2012 which correspond to the status of a poor person. Social and economic situation of each individual of Latvia was significantly influenced by the financial and economic crisis which began in 2008, continued in 2009 and left a serious impact also in 2012. The average disposable income of an equivalent consumer in Latvia continued to decline in 2010 compared to 2008 which was the year before the economic crisis. In 2010, the average disposable income of an equivalent consumer accounted for LVL 300 per month (Fig. 1).

Income decreasing trend started along with the rapid deterioration in the economic situation as a result of the financial and economic crisis, mainly as a loss of job and pay cut, which is reflected in the income of people.

Since 2008, the average disposable income per month decreased by an average of LVL 87; in turn, starting from 2011 average income started to slightly increase reaching LVL 321 a month.

Analyzing income by age groups (see Table 1), in 2010 and 2011, major income was earned by working age people aged from 25-44 years, but the lowest - by young people and people of retirement

\footnotetext{
2 Comes into effect on 1 January 2003.

3 The Cabinet Regulations No. 299 of 30 March 2010 "Regulations on recognition a family or an individually residing person as poor".

4 According to the law "On assistance in housing issues" and the law "On residential tenancy", and what is defined in the rules and regulations binding to the municipality.

5 Section 1, Clause 11 of the law of social services and social assistance.

${ }^{6}$ Section 35 of the law of social services and social assistance.
} 
Int. Conf. SOCIETY. HEALTH. WELFARE.

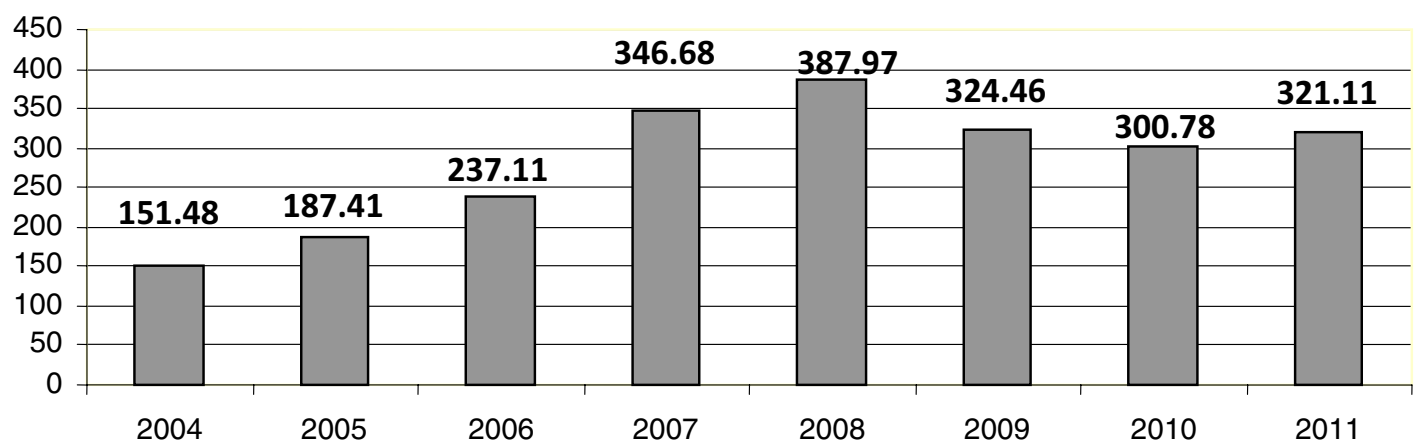

Figure 1. Average disposable income per an equivalent consumer, LVL per month. Data source: Central Statistical Bureau of Latvia.

Table 1. Disposable income by age groups (LVL per month) on average per one equivalent consumer.

\begin{tabular}{|l|l|l|l|l|l|l|l|l|}
\hline & $\mathbf{2 0 0 4}$ & $\mathbf{2 0 0 5}$ & $\mathbf{2 0 0 6}$ & $\mathbf{2 0 0 7}$ & $\mathbf{2 0 0 8}$ & $\mathbf{2 0 0 9}$ & $\mathbf{2 0 1 0}$ & $\mathbf{2 0 1 1}$ \\
\hline In total & 151.48 & 187.41 & 237.11 & 346.68 & 387.97 & 324.46 & 303.18 & 321.11 \\
\hline $0-15$ & 145.89 & 185 & 236.52 & 344.57 & 382.65 & 322.4 & 309.39 & 325.24 \\
\hline $16-24$ & 153.62 & 187.22 & 238.3 & 354.52 & 387.65 & 302.5 & 273.75 & 301.99 \\
\hline $25-34$ & 179.15 & 246.17 & 288.61 & 430.2 & 462.27 & 384.88 & 355.14 & 375.17 \\
\hline $35-44$ & 164.27 & 190.49 & 251.63 & 359.25 & 389.15 & 332.78 & 318.79 & 344.41 \\
\hline $45-54$ & 151.75 & 193.68 & 243.35 & 364.39 & 427.49 & 338.81 & 298.08 & 317.33 \\
\hline $55-64$ & 152.75 & 172.69 & 219.58 & 349.32 & 401.83 & 331.56 & 303.47 & 332.55 \\
\hline $65+$ & 119.88 & 139.37 & 184.6 & 237.41 & 280.76 & 266.82 & 265.74 & 265.22 \\
\hline
\end{tabular}

Data source: Central Statistical Bureau of Latvia.

age. Income is predominantly utilized for food, housing maintenance costs and treatment charges, while consumer expenditure on clothing, shoes, recreation and culture is allocated to the minimum. These groups of exclusion risk due to the low income have limited opportunities for integration into society.

From 2008 till 2010, income fell fastest in the group of young people (16-24 years old) - by $42 \%$, while in the age groups of $45-54$ and 55-64 respectively by $43 \%$ and $32 \%$. This is due to the loss of gainful employment, as the largest proportion of unemployment consisted of 20-24 and 45-59-year-olds in December of $2010^{7}$.

As per the data of the study "Community statistics on income and living conditions", the most affected by the rapid income decrease due to the crisis was Riga and its surrounding region where earlier income used to be higher than the average in the country. The most affected by the economic downturn were the households of self-employed and salaried work force. According to the survey results, by losing a job of economically active members of the household, from $66 \%$ in 2008 to $59 \%$ in 2009, there was a reduction in proportion of the households where the main source of funding was salaried work. At the

\footnotetext{
${ }^{7}$ State Employment Agency data http://www.nva.gov.1v/index.php?cid=6\&mid=297\&txt= 309\&t=stat. Viewed on 08.08 .2012 .
} 


\section{SHS Web of Conferences}

Table 2. Disposable income by quintile groups in 2007-2011 (LVL, on average per household member per month).

\begin{tabular}{|l|r|r|r|r|r|}
\hline Quintile & $\mathbf{2 0 0 7}$ & $\mathbf{2 0 0 8}$ & $\mathbf{2 0 0 9}$ & $\mathbf{2 0 1 0}$ & $\mathbf{2 0 1 1}$ \\
\hline 1 & 70 & 80 & 70 & 67 & 73 \\
\hline 2 & 121 & 143 & 141 & 135 & 139 \\
\hline 3 & 175 & 201 & 183 & 181 & 182 \\
\hline 4 & 259 & 294 & 252 & 239 & 247 \\
\hline 5 & 522 & 576 & 472 & 441 & 479 \\
\hline
\end{tabular}

Data source: Central Statistical Bureau of Latvia.

same time, there was an increase in the proportion of households that subsisted on social transfers, respectively from $29 \%$ to $37 \%$.

Level of income from gainful employment for the working population decreased, and it went down faster than the consumer price level, so the real wage decreased by $5.6 \%$ in 2009 and by $6.5 \%$ in 2010 . Wherewith, along with significant decrease of the real income of population, an increase in the number of households subjected to poverty happened. Survey data shows that $85 \%$ of households in 2010 (82\% in 2009) faced a challenge to stand the daily expenses ${ }^{9}$ to a greater or lesser extent.

Already in 2009 , the economic strain ${ }^{10}$ was felt by $62.2 \%$ of households, and according to the fact sheet of the Central Statistical Bureau "On material deprivation in Latvia" in 2010, the number had increased and $65.8 \%$ of households acknowledged the tension, in addition to that, the economic strain increase was equally observed in almost all quintile ${ }^{11}$ groups, but the fastest increase was in the households of $3^{\text {rd }}$ and $4^{\text {th }}$ quintile (respectively 6.7 and 7.3 percentage points)

It should be noted that the fastest growth of economic stress in 2009 was observed in the households of $5^{\text {th }}$ quintile (10.6 percentage points), which becomes easily understandable seeing Table 2 , where it is shown that disposable income per household member on average per month in the households of the $5^{\text {th }}$ quintile in 2010 , compared to the year 2008 , decreased by $135 \mathrm{LVL}$.

As we see can in Table 2, from 2011, income in all quintile groups is minimal but it starts to increase.

An assessment of the proportion of households, which could not afford to cover some expenses (to cover utility bills, rent or to repay the credit) due to the lack of money in 2011, by quintiles, can be seen Table 3. As we see, the highest percentage is in the $1^{\text {st }}$ quintile group $(46 \%)$ and the number is high also in the $2^{\text {nd }}$ quintile group where almost $30 \%$ of households could not afford to cover some of

\footnotetext{
${ }^{8}$ As per the EU-SILC methodology, social transfers are considered state, municipality granted pensions and benefits, alimony paid, grants, Social Security benefits and compensation, including the ones granted by other countries.

9 http://www.csb.gov.lv/notikumi/par-iedzivotaju-ienakumiem-un-dzives-apstakliem-2010-gada-31954.html.

10 As per the EU-SILC survey methodology, economic strain is determined by the number of questions, in which respondents evaluated the ability of households to bear such costs:

- To eat meat, poultry or fish every alternate day;

- To go on a one week vacation outside home every year;

- To cover unexpected expenses from their own resources;

- To financially maintain a warm place of living;

- To cover utility bills, pay rent or cover the purchases made on credit (to repay the credit).

Households that give a negative answer to at least two questions, are considered being subjected to economic strain.

11 Quintile is one fifth $(20 \%)$ the number of households surveyed listed in ascending order of their disposable income per one member of the household. The lowest (first) quintile includes a fifth of households with the lowest income, but the highest (fifth) - a fifth of households with the highest income.
} 
Int. Conf. SOCIETY. HEALTH. WELFARE.

Table 3. The proportion of households, which could not afford to cover some costs due to the lack of money in 2011 , by quintiles $(\%)$.

\begin{tabular}{|l|c|c|c|c|c|}
\hline $\begin{array}{l}\text { Quintile/ } \\
\text { Indicator }\end{array}$ & $\begin{array}{c}\mathbf{1 .} \\
\text { 73Ls/month) }\end{array}$ & $\begin{array}{c}\mathbf{2 .} \\
\text { (139Ls/month) }\end{array}$ & $\begin{array}{c}\mathbf{3 .} \\
\text { (182Ls/month.) }\end{array}$ & $\begin{array}{c}\mathbf{4 .} \\
\text { (247Ls/month) }\end{array}$ & $\begin{array}{c}\mathbf{5 .} \\
\text { (479Ls/month) }\end{array}$ \\
\hline $\begin{array}{l}\text { To cover utility bills, } \\
\text { rent or to repay the } \\
\text { credit }\end{array}$ & 46 & 28.2 & 18.2 & 17.4 & 10.4 \\
\hline $\begin{array}{l}\text { To maintain a } \\
\text { warm place of } \\
\text { living }\end{array}$ & 40.6 & 28.2 & 24.6 & 17.3 & 9.3 \\
\hline $\begin{array}{l}\text { To cover } \\
\text { unexpected } \\
\text { expenses of Ls } 195\end{array}$ & 93.6 & 91.8 & 89.5 & 75.3 & 56.9 \\
\hline $\begin{array}{l}\text { To go on a one } \\
\text { week vacation } \\
\text { outside home } \\
\text { every year }\end{array}$ & 81.5 & 73.6 & 74.3 & 55.9 & 31.3 \\
\hline $\begin{array}{l}\text { To eat meat, } \\
\text { poultry or fish } \\
\text { every alternate day }\end{array}$ & 54.3 & 40.3 & 37.9 & 21.1 & 10.9 \\
\hline
\end{tabular}

Data source: Central Statistical Bureau of Latvia.

their expenses. The figures are alike also when talking about the ability to maintain a warm place of living. An alarming is also the fact that quite high number of households of $1^{\text {st }}-3^{\text {rd }}$ quintile $\left(54 \%\right.$ of $1^{\text {st }}$ quintile households and $40 \%$ of $2^{\text {nd }}$ and $3^{\text {rd }}$ quintile households) could not afford eating meat, poultry or fish every alternate day.

Decrease of household income significantly increased the number of poor persons. The status of a poor family (person) shall be determined in accordance with The Cabinet Regulations No. 299 of 30 March 2010 "Regulations on recognition a family or an individually residing person as poor". These regulations provide that the family (person) shall be recognized as poor where the average income per each member of the family per month in the past three months does not exceed LVL 90 and the material status does not exceed the level provided for in the same regulations.

National Statistics reports on social assistance show the dynamics of the number of poor persons in the time period from 2004, before the economic crisis, until 2011. The government had granted the status of a poor person to 120 thousand people in 2008, and the number of poor persons rose to 282 thousand in 2010.

Along with the rise in unemployment, a decline in the number of vacancies was observed and a change in the structure of the recipients of local social assistance happened.

Due to the fact that for the award of the local social assistance benefits a family or a household is evaluated as a whole, also information on composition of families or households is provided in the National Statistics reports.

According to the information from the Fact report of the Welfare ministry on the pace of reform in social assistance system, the number of social assistance receiving families with children having one or more adult able-bodied persons was two times higher in 2011 than it was in 2008. During this period, the number of social assistance receiving families with adult able-bodied persons and no children increased more than three times (Fig. 2). This means that the crisis led to a change in the local social beneficiary's "portrait" - the leading position was taken by the families with adult able-bodied persons. Considering that income of a family is based on the earnings from work, poverty, as has already been mentioned, is 
SHS Web of Conferences

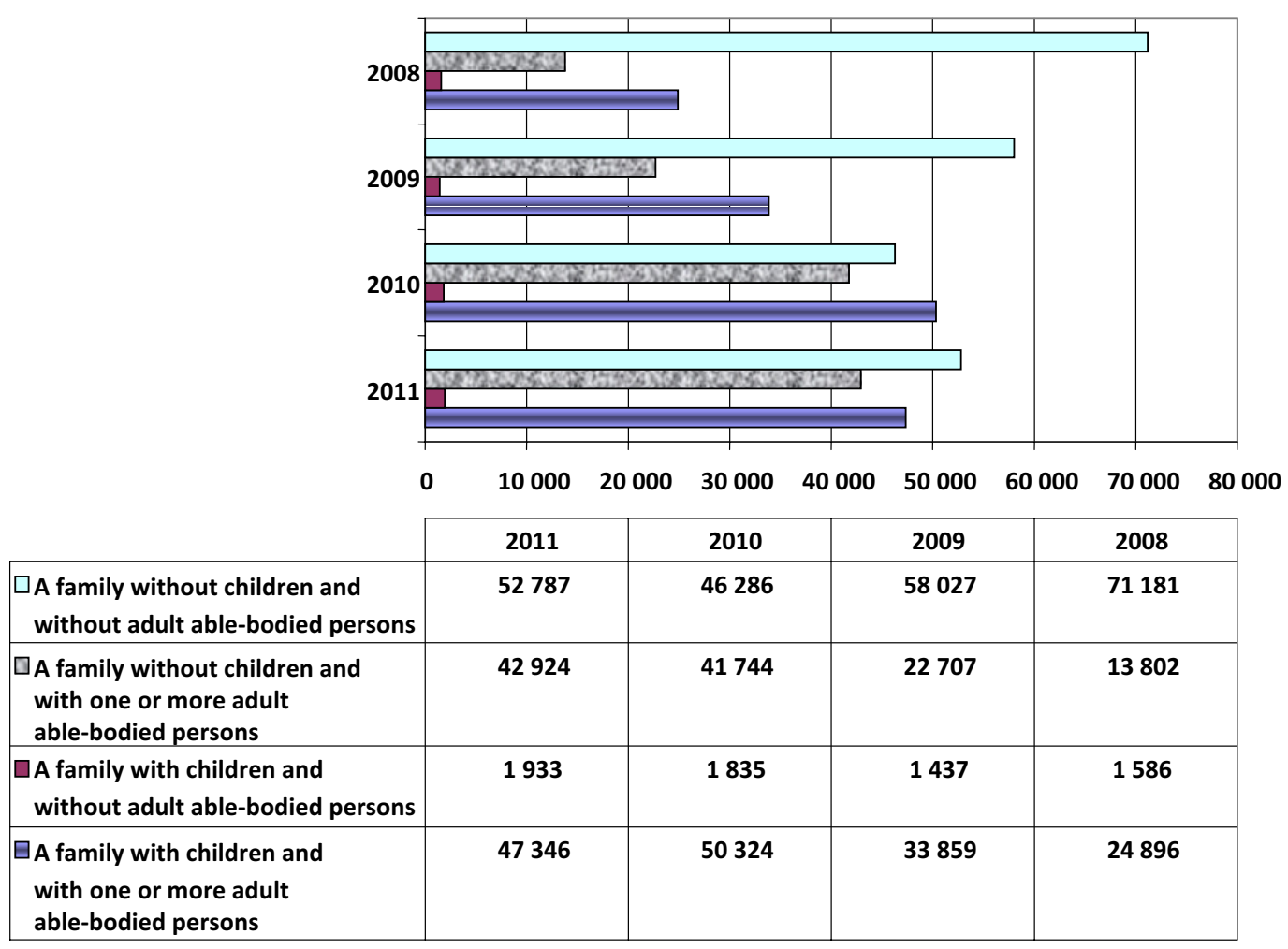

Figure 2. Dynamics of the recipients of income tested social assistance benefits by composition of family in 2008-2011. Data source: National statistical annual reports on social asistance.

significantly dependent on employment of parents. The main risk of poverty in families with children is unemployment.

The latest data of National Statistics report of 2012 prove that the highest proportion of the total number of poor persons in 2012 consists of adult able-bodied non-employed persons (39\%) and the second largest group consists of children from families that are acknowledged as poor (33\%) (Fig. 3).

More than $75 \%$ of all the persons receiving local social assistance benefits are persons who comply with the status of a poor person (hereinafter referred to as poor.

Statistical data of local social services of the cities of Latvia show that the proportion of nonworking adult able-bodied persons in the total number of poor persons in July of 2012 was the highest in Rēzekne (50.5\%) and Jēkabpils (43.1\%) (Fig. 4). The average proportion of non-working adult ablebodied persons in the total number of poor persons in the country was 38.8\% in July of 2012.

According to the operational information of State Employment Agency, the highest registered level of unemployment ${ }^{12}$ in July 2012 was in the cities of Rēzekne and Jēkabpils - respectively $20.9 \%$ and $16.1 \%$ (the average in the country was $11.6 \%$ ).

We may conclude that the municipalities with the highest unemployment have also the highest number of beneficiaries of social assistance benefits and the highest proportion of non-working adult able-bodied persons in the total number of poor people. Note, however, that there is also a large number of working poor persons. They are mostly parents of large families or families where children are

12 Registered level of unemployment of economically active population. 


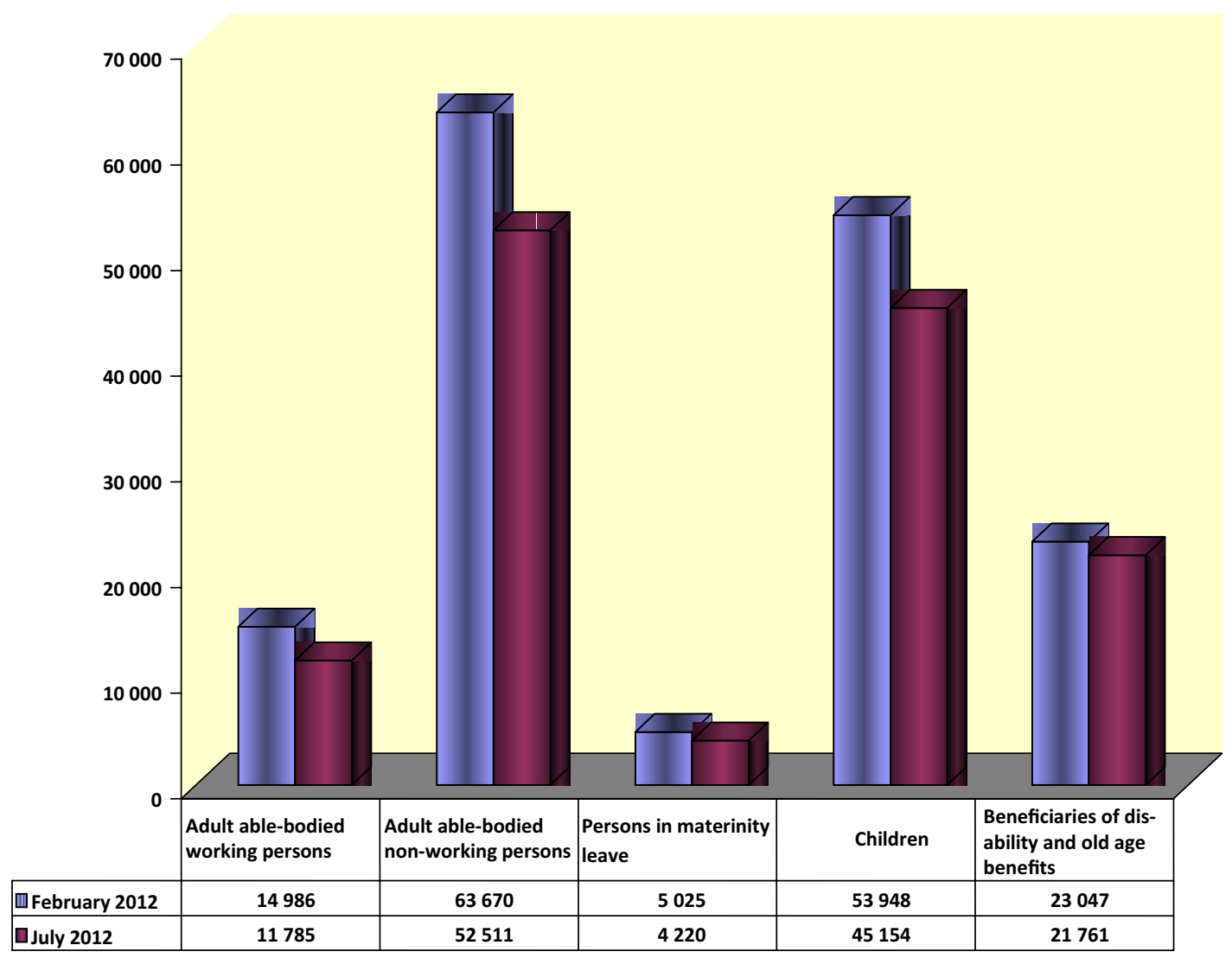

Figure 3. Number and structure of persons recognized as poor in Latvia in the months of February and July 2012. Data source: National statistical annual reports on social asistance.

brought up by one of the parents. Relatively small is the number of persons which comply with the status of a poor family (person) while being in maternity leave, the highest number of such persons is in Riga (Fig. 5).

Among the receivers of social assistance benefits are both persons with health problems, as well as people who work in paid employment and receive remuneration insufficient to meet the household needs, unemployed persons who are not in demand in the labour market due to their poor skills and low qualification.

In addition, social assistance is often received people who care for family members (children, the elderly, disabled people, etc.) because there have not been sufficiently developed forms of alternative care such as "nanny service", home care, day care centres, group homes etc within the municipality.

Evaluation of the situation over the years (see Table 4), indicates that the crisis has led to an emergence of new trends. If until 2008 (including), pension age people have been most at risk of poverty, and children and young people the least, the crisis affected situation is now reversed. In addition, these differences are very significant. The at-risk-of-poverty index of pension age people was 2 times higher than for children and young people in 2007 and 2008. But after the crisis, the index is completely different in the year 2010; the risk of poverty for children and young people is two to three times higher than for people of retirement age. Young people are the second largest population group, which has the highest risk of poverty. In addition, since 2008 it is constantly increasing. The group of young people is 


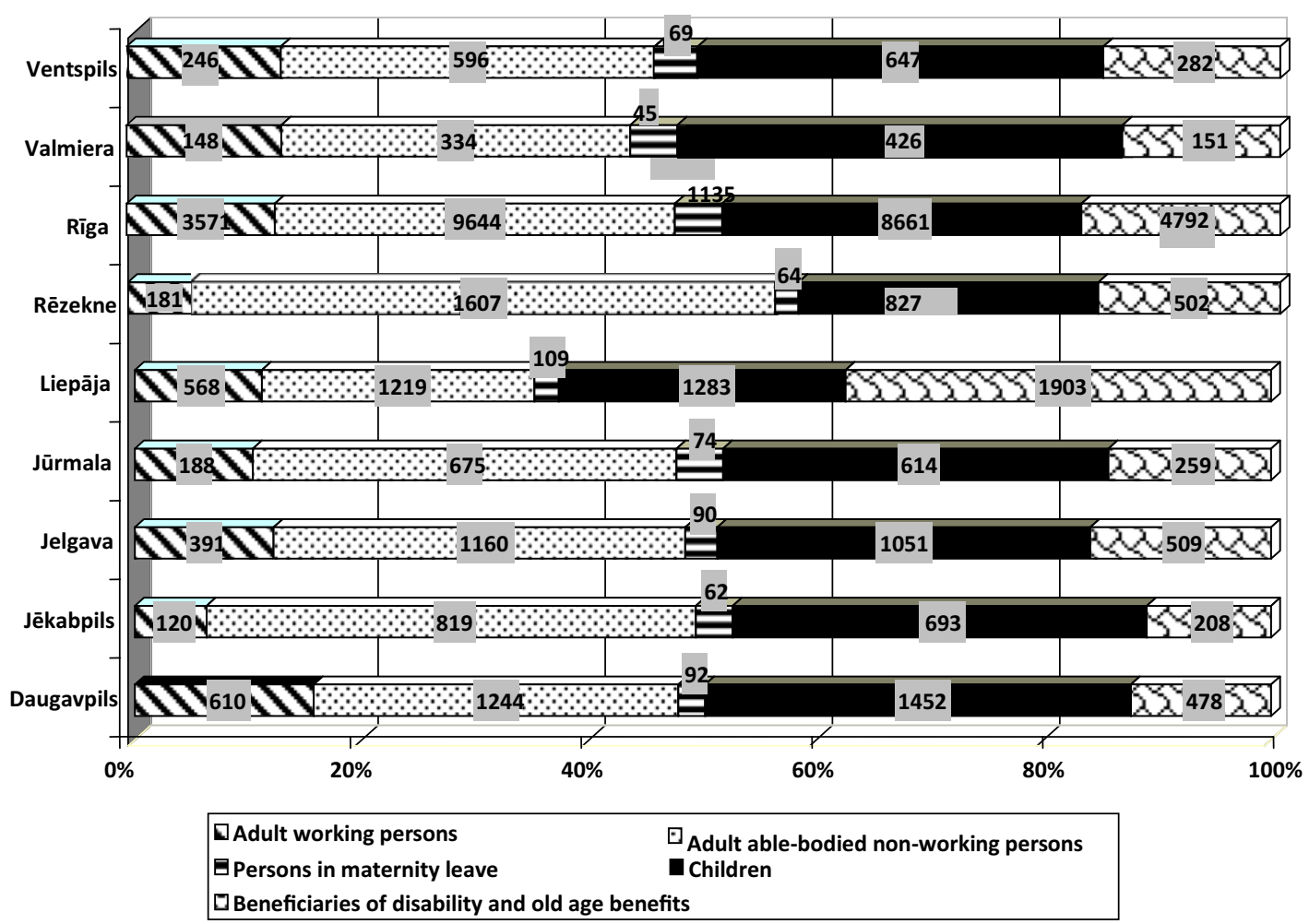

Figure 4. Information on the number and composition of poor persons in the cities of Latvia in July 2012, as submitted by municipalities. Data source: National statistical annual reports on social asistance.

followed by the group of working age people and pre-retirement age people aged 50-64, for whom the risk of poverty is declining since 2008 , however, it is still relatively high. The risk of poverty has a very mild change for the population aged 25-49, and it remains within $19 \%$.

As mentioned above, for people of pre-retirement (60+) and people of retirement age $(65+, 75+)$, the risk of poverty is the lowest, and the older is the person, the lower is the risk of poverty, which is also the opposite trend to the pre-crisis period, when the risk of poverty increased along with increase of age.

Analyzing the risk of poverty of working people (see Fig. 5), it shows that in 2010, the workers in pre-retirement age (55-64) were at most at risk of poverty. In addition, this is the only age group where, in 2010, the risk of poverty increased, not decreased, compared with other age groups.

Crisis increased part-time employment which resulted in decrease of income from employment. The evaluation of monetary indicators of poverty by the Central Statistical Bureau, the most affected by the risk of poverty as per household work intensity in 2007 were families with unemployed breadwinner (respectively families with children $76 \%$ and family without children $-71 \%$ ) and families with breadwinner having less than part-time employment (45\%). It should be noted that the proportion of part-time workers whose employment may be undeclared, which affects their risk of poverty in a situation of lay-off when they would not receive Social Guarantees to the extent that could be received when paying Social Security contributions in full. In order to minimize the negative social impact of the financial and economic crisis and the consequences, a Social Security Network Strategy was implemented in the country from the autumn of 2009 till the end of 2012, creating safeguard measures for emergency situations in the areas of welfare, education, health care and transport. As one of the 
Int. Conf. SOCIETY. HEALTH. WELFARE.

Table 4. At-risk-of-poverty index by age in 2004-2010.

\begin{tabular}{|l|l|l|l|l|l|l|l|l|}
\hline & Total & $\mathbf{0 - 1 7}$ & $\mathbf{1 8 - 2 4}$ & $\mathbf{2 5 - 4 9}$ & $\mathbf{5 0 - 6 4}$ & $\mathbf{6 0}+$ & $\mathbf{6 5}+$ & $\mathbf{7 5}+$ \\
\hline 2004 & 19.2 & 21.5 & 16.9 & 17.1 & 20.3 & 20.7 & 21.2 & 22.1 \\
\hline 2005 & 23.1 & 25.8 & 18.3 & 18.5 & 26.2 & 30.3 & 29.8 & 32 \\
\hline 2006 & 21.2 & 20.5 & 17.2 & 16.3 & 23.2 & 32.6 & 33.3 & 35.9 \\
\hline 2007 & 25.6 & 24.6 & 17.1 & 17.7 & 25.1 & 46.2 & 51.2 & 57.9 \\
\hline 2008 & 25.7 & 25.7 & 19.2 & 19.2 & 23.3 & 43.2 & 47.5 & 54.3 \\
\hline 2009 & 21.3 & 26.6 & 21.2 & 19.9 & 21.1 & 19.6 & 18.8 & 19 \\
\hline 2010 & 19.3 & 24.8 & 22.4 & 19.2 & 21 & 11.4 & 9.5 & 8.9 \\
\hline
\end{tabular}

Data source: Central Statistical Bureau of Latvia.

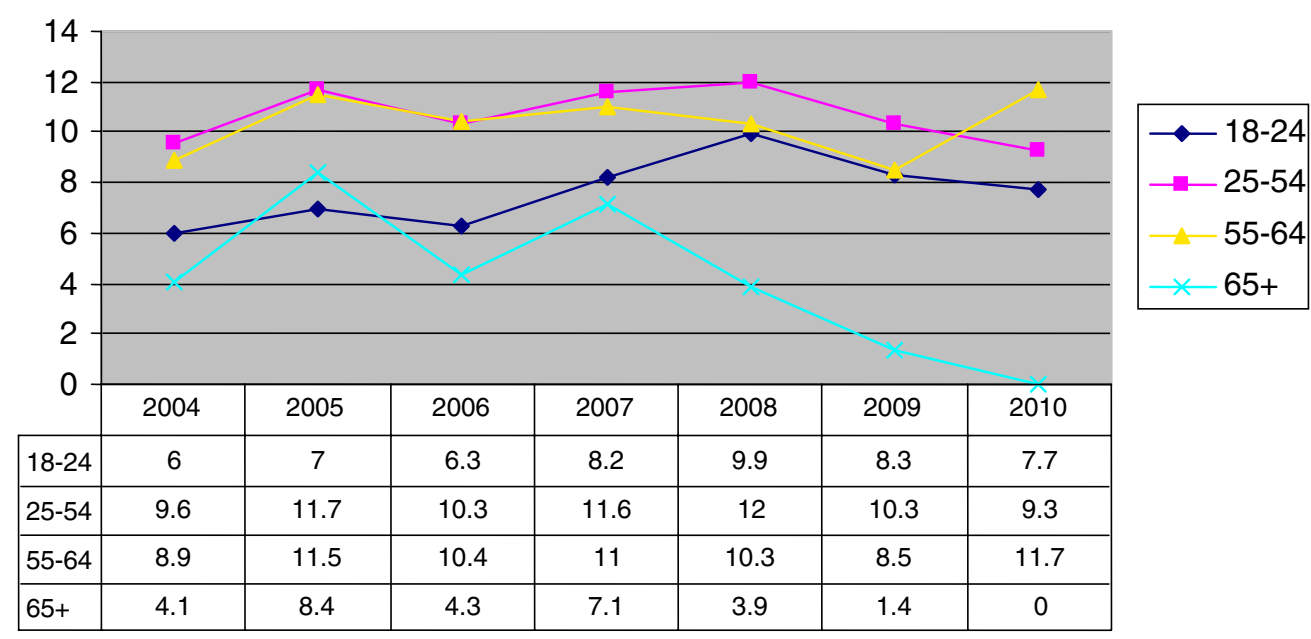

Figure 5. At-risk-of-powerty index of working people in 2004-2010. Data source: Central Statistical Bureau of Latvia.

measures was providing state aid to local governments for payment of social assistance benefits in accordance with the terms of the Social Security Network Strategy ${ }^{13}$ (from 1 October 2009 till 31 December 2012, national co-financing contributes $50 \%$ of the funds used by local government for GMI benefits and till 30 April 2012 - 20\% of the funds used by local government for housing benefit).

GMI level was increased from LVL 27 per person per month to LVL 37 from 1 January 2009, and further increased to LVL 40 for an adult and LVL 45 for a child in the fourth quarter of 2009.

The amendments adopted within the law ${ }^{14}$ in late 2009 lay down that also other local government social assistance benefits to be granted after assessment of household income (excluding a one-off allowance in case of an emergency).

2009. The amendment to the law in 2009 provided an opportunity to receive social assistance, including GMI benefits, also to the people who have loan balances, which they were denied before.

13 Approved by the minutes No. $5678 \S$ of proceedings of the Cabinet on 8 September 2009.

14 Amendments of the Law on 29 October 2009. 


\section{SHS Web of Conferences}

As a result of the above mentioned events, based on the National annual statistical report data on social assistance for basic social assistance benefits - the GMI allowance and housing benefit the proportion of the total budget expenditure spent on municipal social assistance in the country had increased on average from $40.6 \%$ in 2008 to $72.6 \%$ in 2001. Respectively, an average amount of GMI allowance per person a month in this period increased from LVL 17 in 2008 to LVL 26.65 in 2011.

National statistics annual report data show that total spending on social assistance in the period of time from 2006 to 2011 increased without a significant rise in the total number of social assistance recipients.

The amount utilized for GMI allowances in 2011 increased more than ten times a year compared to 2008, while the number of beneficiaries of GMI allowance during that period increased only 4.5 times. The proportion of the beneficiaries to the total number of social assistance recipients of GMI allowance increased from $8.5 \%$ in 2008 to $36.9 \%$ in 2011. It shows that a large part of municipalities were ready to implement a social assistance system only with national co-funding and more stringent conditions laid down in the laws and regulations of the country. The operation of the strategy was originally set as December $31^{\text {st }} 2011$, but after the assessment of the social and economic situation at the end of 2011, the Cabinet, in agreement with the Latvian association of local and regional governments, decided to continue supporting national governments in 2012 by co-financing $50 \%$ of the expenditures of local governments used for GMI benefits for the period from 1 January 2012 till December $31^{\text {st }} 2012$. This way a targeted support was provided for people with the lowest income. Nothing was changed in the framework of social assistance system along with the introduction of fixed-term state funding for local authorities (from October 2009 to 31 January 2012) - the main benefit administrators still were local authorities (prior to allocation of the allowance authorities shall carry out a thorough evaluation of material situation of the person/household), and basically, local government still remained the primary source of financing of the system (then half of the amount of financing paid out by authorities was co-financed from the state government). Thus, it may be stated that no element of centralization was introduced in the social assistance system implemented in Latvia, when the fixed-term state government co-financing was introduced.

Monitoring by selected indicators was performed throughout the period of Social Safety Net Strategy, and, towards the end period of the strategy, a tendency was observed that the number of persons with a status of a poor person was gradually decreasing (from 190.8 thousand persons in March 2011, when the highest number was registered, to 112.3 thousand in November 2012), and also proportion of such persons in the total population was reducing (respectively - from $9.2 \%$ to 5.5\%). Also the number of recipients of GMI allowance had a downward trend at the final stage of the Strategy if 79.6 thousand persons received GMI allowance in the month of March 2011, then the number of beneficiaries decreased to 41.1 thousand as per preliminary data in November 2012, which is $36.6 \%$ of the persons identified as poor (respectively - from $3.6 \%$ to $2.0 \%$ of the population). Given that the number of beneficiaries of GMI allowance has decreased in 2012 and the national economic situation is improving, it scheduled to retrieve the previously established approach to the social assistance benefit funding with the above mentioned benefits again being fully funded from the budget of local authorities. From 1 January 2013, GMI level is defined for LVL 35 per person a month, while municipal council is delegated the right to determine a higher level (up to LV 90) for different groups of population (e.g., children, old age and invalidity pension beneficiaries). It should be taken into account that this provision allows local authorities to more flexibility determine GMI level in accordance with the specific situation of the area, at the same time ensuring that the lowest GMI level is complied with throughout the country. Interviewing local authorities, the majority (including municipality of Riga city) does not intend to reduce the amount of the benefit provided in 2013. All of the above mentioned measures and the provision of aid in the financial and economic crisis was significant support for persons and households with low income, to the ones with status of poor people, as well as other groups of the 
Int. Conf. SOCIETY. HEALTH. WELFARE.

population, who received a fare preferences and which were secured work placements in municipalities at the time of high unemployment rate.

\section{Conclusions}

Statistical data show that, in the period between 2006 and 2011, the total spending on social assistance increased without a particular change in the total number of social assistance beneficiaries (Fig. 6). Funds spent on GMI allowance in 2011 grew more than ten-fold compared to 2008, while number of beneficiaries of GMI allowance during the same period increased only 4.5 times (Fig. 5). Proportion of GMI beneficiaries to the total number of social assistance recipients increased from $8.5 \%$ in 2008 to $36.9 \% 2011$ (Fig. 6). This proves that a large part of municipalities were ready to implement a social assistance system only with national co-funding and more stringent conditions laid down in the laws and regulations of the country.

It is necessary to continue to implement a number of measures that will promote opportunities for able-bodied persons to return to the labour market in order to reduce the need to apply for social assistance.

The functions defined for municipalities are carried out and funded by the tax and fee revenues - the tax revenues that are apportioned between the state and local governments - personal income tax, property tax, and the tax revenues from local lotteries, the tax on the use of radioactive materials, the gambling tax and other taxes and duties. In cases where negotiations on re-allocation of functions between the state and local authorities are initiated, accordingly changes in the distribution of tax revenue have to be enforced.

One of the policy agenda issues is reduction of poverty risk of workers. Statistics show that the deep economic crisis and continuing high unemployment have created lasting consequences in society and social exclusion and poverty issues still remain a high priority. Similarly, the figures indicate that increased profits of working age people at the moment are crucial to reduce the risk of poverty for workers, which in turn affects well-being of children and people of retirement age. Consequently, there is the need to think about measures to address these issues (changes in social insurance legislation on parental benefits, new active labour market policies, and support for families with children and implementation of service for integration of disabled people).

In 2010, for the first time in the last five years, a situation developed that higher social assistance benefit was paid to households with the lowest incomes, i.e., those with the lowest income (less than GMI level) received a larger amount of social assistance benefits (the average amount of social assistance benefit was LVL 202.62 per person a year) and persons with higher income (above the level of income of a poor person) received a lower amount of social assistance benefits (the average amount of social assistance benefit was LVL 104.05 per person a year). For persons/households with income above the level of income of low-income families (persons), material support was primarily provided in the form of housing benefits (for low-income families or single persons). Only in the event of a crisis, local governments began to understand their role and place in the social security system and to implement what was specified in the European Charter of Local governments that the services have to be provided by the level of government closest to the people - municipal social assistance was granted to targeted families or single persons with lower income. Consequently, a shift in the composition of social assistance recipients took place in the situation of crisis (by the means of national co-financing and raising of GMI level) - from old age and disability pension recipients to families with children and the unemployed who have lower income or none at all. 
SHS Web of Conferences

\section{References}

[1] Central Statistical Bureau, [electronic resource]: http://data.csb.gov.lv/DATABASE/ Iedzsoc/Ikgadējie\%20statistikas\%20dati/Monetārās\%20nabadzības\%20un\% 20 ienākumu\%20nevienlīdzības\%20indikatori/Monetārās\%20nabadzības\%20un\% 20 ienākumu\%20nevienlīdzības\%20indikatori. asp. Viewed on 6 February 2013.

[2] State Employment Agency, [electronic resource]: http://www.nva.gov.1v/index.php?cid= $6 \& \mathrm{mid}=330$. Viewed on 5 November 2012.

[3] The law "On assistance in housing issues", [electronic resource]: http://www . likumi.1v/doc . php?id=56812. Viewed on 10 November 2012.

[4] The law "On residential tenancy" [electronic resource]: http://www.likumi.lv/doc.php?id= 56863. Viewed on 10 November 2012.

[5] Lombardi T.P., Inclusion: Policy and Practice, Phi Delta Kappa, Educational Foundation, 1999, P.10.

[6] The Cabinet Regulations No. 299 of 30 March 2010 "Regulations on recognition a family or an individually residing person as poor" [electronic resource]: http://www. likumi. lv/doc.php? id=207462. Viewed on 20 December 2012.

[7] Social Security Network Strategy, [electronic resource]: http://www.likumi.lv/doc.php?id= 202432. Viewed on 10 November 2012.

[8] The law of social services and social assistance, [electronic resource]: http://www.likumi.lv/ doc.php?id=68488. Viewed on 10 November 2012. 